\title{
The Effectiveness of Booklet of Anemia on the Behaviors of Adolescent Girls
}

\author{
Maida Pardosi ${ }^{1}$ \\ ${ }^{1}$ Poltekkes Kemenkes Medan, Medan Province, Indonesia \\ Correspondence: Maida Pardosi, Poltekkes Kemenkes Medan, 20141, Indonesia. Tel: 62-813-9604-5555. E-mail: \\ rumelia.lubina@yahoo.co.id
}

Received: July 26, 2019 Accepted: August 12, 2019 Online Published: August 19, 2019

doi:10.5539/gjhs.v11n10p111 URL: https://doi.org/10.5539/gjhs.v11n10p111

\begin{abstract}
The prevalance of anemia shows an ascending trend annually in Indonesia. The Indonesia Demographic and Health Survey in 2012 reported that the prevalence rate of anemia in Indonesia for adolescent girls in the categories of 5-14 years of age and 10-19 years of age and of 15-24 years of age were 21.7\%, 18.4\% and $18.4 \%$ respectively. Based on the premilinary survey of North Sumatera Health Survey in 2017, there were 322 thousand adolescent girls had symptoms of anemia. The uppermost prevalence levels of anemia incidences in this province were reported in Binjai, Langkat, Deli Serdang, SerdangBedagai and Tebing. According to the preliminary survey among school adolescent girls at the State Senior High School SMA I KutalimBaru in Deli Serdang regency, there were 15 students took breakfast daily, 10 students sometimes took breakfast, 5 students almost never take breakfast, and 12 students limited their food and beverage consumption daily and never obtained health counseling pertaining to anemia.Concerning to this fact, the authors of the present study intended to assess the effectiveness of booklet of anemia on the behavior of school adolescent girls at the State Senior High School I KutalimBaru of Deli Serdang regency in 2018. The sample size was 156 students and samples were divided into two groups, 78 students for the intervension group and 78 students for the control group using stratified random sampling method. Results of the study revealed that the effectiveness of booklet on the knowledge, attitude and hemoglobin levels showed significant difference between the intervention group and the control group with $\rho$-value $(0.000)<\alpha(0.05)$. It was concluded that booklet of anemia gave a significant impact to the improvement of knowledge, attitude and hemoglobin levels due to anemia. It was suggested to encourage student adolescent girls to consume balanced nutrition, read booklet of anemia, increase and distribute up-date health guidance of anemia and further studies related with the practice of booklet of anemia for adolescent girls in enhancing their life healthy behaviors, such as menstruation, eating behaviors, resting pattern and other healthy behaviors associated with anemia.
\end{abstract}

Keywords: effectiveness of booklet, adolescent girls, behavior about anemia

\section{Introduction}

Anemia is a term referring to a reduction in the number of red blood cells, hemoglobin concentration, or oxygen-binding capacity of $\mathrm{Hb}$ (McLean, 2009). The most common cause of anemia all over the world is lack of iron in micronutrients (WHO, 2012) due to lack of available iron to support normal red cell production (Ciesla, 2011) and it is correlated with decreased cognitive performance (Sachdev et al., 2005; Glazer \& Bilenko, 2010), impaired tissue oxygen delivery, weakness, fatigue, difficulty concentrating, or poor work productivity (Haas \& Fairchild, 1989). Children may have issues with mental and motor development (McCann \& Ames, 2007; Beard \& Connor, 2003). Iron-deficiency anemia, especially when severe, is correlated with increased risk of preterm labor, low birth weight (Rasmussen, 2001) and child and maternal mortality (Brabin et al., 2001) and may predispose to infection (Dunne et al., 2002) and heart failure (Anand, 2008).

According to the report from WHO, the prevalence of anemia around the world was $40.88 \%$ in 2013 . In terms of the national level, the Indonesia Demographic and Health Survey in 2012 reported that the prevalence rate of anemia in Indonesia for adolescent girls in the categories of 5-14 years of age and 10-19 years of age and of 15-24 years of age were $21.7 \%, 18.4 \%$ and $18.4 \%$ respectively (Ministry of Health of the Republic of Indonesia, 2014). In view of the provincial level, there were 322 thousand adolescent girls had anemia symptoms for all provinces in 2017. The uppermost prevalence levels of anemia incidences in this province were Binjai, Langkat, Deli Serdang, SerdangBedagai and TebingTinggi (Regional Health Department of North Sumatera, 2017). 
The main important periods in which the need of sufficient and balanced nutrition is the adolescence periods, where growth and development are accelerated (Spear, 2002). Adolescence are periods when good nutritional diet quality is important to establish healthy dietary behaviors. The influence of peer environment, mass-media, celebrities and school nutrition programs increases rapidly during adolescence (Spronk, 2014). Thus, early adolescence may be the last moment for implementing sustained healthy school culture and nutrition education addressed to young people before determining their relatively stable eating habits. In this regard, schools are considered as a primary setting for implementing education programs (Hamulka et al., 2018).

Multiple studies have evaluated knowledge and attitude of adolescent girls pertaining to anemia in the developing countries including in Indonesia (Sinaga, 2013; Caturiyantiningtiyas, 2015; Arini et al., 2017) or outside Indonesia (Baral \& Onta, 2009; Shojaeizadeh, 2001; Tesfaye et al., 2015; Angadi \& Ranjitha, 2015; Jalambo et al., 2017; Hamnal et al., 2018).

In view of the local context, the authors of this study conducted the preliminary survey at the State Senior High School I KutalimBaru in Deli Serdang on Januari 2018. Among 30 students, there were 15 students took breakfast daily, 10 students sometimes took breakfast, 5 students almost never take breakfast, and 12 students limited their food and beverage consumption daily and never obtained health counseling pertaining to anemia. Concerning to this fact, this present study was aimed to assess the effectiveness of booklet of anemia on the knowledge, attitude and hemoglobin levels of adolescent girls at the State Senior High School I KutalimBaru in Deli Serdang regency in 2018 .

\section{Methods of the Study}

\subsection{Sample Populations and Design of the Study}

This study was a cross-sectional study and the samples of this present study were students of the Class X and the Class XI at the State Senior High School 1 KutalimBaru in Deli Serdang. The study was conducted from January until April 2018. The present study compared knowledge, attitude and $\mathrm{Hb}$ levels between the intervention group by giving booklet of anemia and the control group without giving booklet of anemia. Minimum sample size for each group was determined using a simple mean formula, $N=(1.96 \times \sigma / \Delta)^{2}$, with the standard deviation $(\sigma)$ of 3.4 and the effect size $(\Delta)$ of 0.75 (Mitra et al., 2012; Lim et al., 2018). Hence, minimum sample size was 78 respondents for each group and the total samples for the control group and the intervention group were 156 respondents. Theexperimental design used in this present study was two-group pretest-posttest design by comparing two different group tests that consisted of the intervention group $(\mathrm{n}=78)$ and the control group $(\mathrm{n}=78)$ (Siswosudarmo, 2015). Collection of the study samples was performed using the stratified sampling method.

\subsection{Measurement of Knowlegde, Attitude and Hemoglobin Levels}

The research instrument to collect data of knowledge and attitude of respondents was questionnaire in the form of multiple choice questions that consisted of 10 items of questions for measurement of knowledge and 6 items of questions for measurement of attitude that referred to format of questionaires derived from the widely used Demographic and Health Survey (DHS) (DHS, 2012), Key Indicators Survey (DHS, 2012) and the study of Angadi and Ranjitha (2016) with some modifications in accordance with the local context of this present study. In addition, interviews were conducted among respondents.

Determination of normal $\mathrm{Hb}$ level and non-normal $\mathrm{Hb}$ level referred to the hemoglobin values less than $11 \mathrm{~g} / \mathrm{dL}$ of blood (WHO, 2001). Therefore, normal $\mathrm{Hb}$ level and non-normal $\mathrm{Hb}$ level of respondents in this present study were determined in the range of $12-16 \mathrm{gr} / \mathrm{dL}$ of blood and of $<12 \mathrm{gr} / \mathrm{L}$ of blood respectively. The method used to measure $\mathrm{Hb}$ levels of respondents used the HemoCue method.

\subsection{Ethical Considerations}

All procedures for the treatment of respondents were reviewed and approved by the Research Ethics Committee of the Medan Health Polytechnic.

\subsection{Data Management and Analysis}

Statistical tests used in this present study consisted of normality test, univariate analysis and bivariate analysis with the comparison of data of knowledge, attitude and hemoglobin levels between the intervention group and the control group.Knowledge, attitude and hemoglobin levels were analyzed using unpaired samples t-test at the $95 \%$ significant level $(\alpha=0.05)$.Student t-test was used to compare hemoglobin levels between the control group $(\mathrm{n}=$ $78)$ and the intervention group $(\mathrm{n}=78)$. The collected data were processed and analyzed using SPSS version 17. 


\section{Results}

\subsection{Univariate Analysis}

Table 1. Frequency distributions of the category of attitude of respondents for the useof booklet of anemia

\begin{tabular}{llllll}
\hline \multirow{2}{*}{ Attitude of Respondents } & \multicolumn{2}{l}{ Intervention Group } & & \multicolumn{2}{c}{ Control Group } \\
\cline { 2 - 3 } \cline { 5 - 6 } & $\mathbf{n}$ & $\mathbf{0}$ & $\mathbf{n}$ & $\mathbf{\%}$ \\
\hline Positive & 78 & $50 \%$ & 78 & $50 \%$ \\
Negative & 78 & $50 \%$ & 78 & $50 \%$ & $100 \%$ \\
\hline Total & $\mathbf{1 5 6}$ & $\mathbf{1 0 0} \%$ & $\mathbf{1 5 6}$ & \\
\hline
\end{tabular}

As shown in Table 1, 78 respondents (50\%) were given the booklet of anemia in the intervention group and 78 respondents $(50 \%)$ were not given the booklet of anemia in the control group with the total number of respondents were 156 respondents.

Table 2. Frequency distributions of the category of knowledge of respondents for the use of booklet of anemia

\begin{tabular}{|c|c|c|c|c|c|c|}
\hline \multirow{2}{*}{ Knowledge of Respondents } & \multicolumn{2}{|c|}{ Intervention Group } & \multicolumn{2}{|c|}{ Control Group } & \multicolumn{2}{|c|}{ Total } \\
\hline & $\mathbf{n}$ & $\%$ & $\mathrm{n}$ & $\%$ & $\mathbf{n}$ & $\%$ \\
\hline Good & 28 & 35.90 & 4 & 5.13 & 32 & 20.51 \\
\hline Moderate & 45 & 57.69 & 47 & 60.26 & 92 & 58.98 \\
\hline Poor & 5 & 6.41 & 27 & 34.62 & 32 & 20.51 \\
\hline Total & 78 & $100 \%$ & 78 & $100 \%$ & 156 & $100 \%$ \\
\hline
\end{tabular}

In Table 2, frequency distributions of respondents regarding the knowledge of the use of booklet of anemia for the intervention group in the category of good, of moderate, and of poor are 28 respondents (35.90\%), 45 respondents $(2.9 \%)$ and 5 respondents $(5.9 \%)$ respectively, whereas, frequency distributions of respondents regarding the knowledge of the use of booklet of anemia for the control group in the category of good, of moderate, and of poor are 4 respondents (5.13\%), 47 respondents $(60.26 \%)$ and 27 respondents $(34.62 \%)$ respectively.

Table 3. Frequency distributions of the category of attitude of respondents for the use of booklet of anemia

\begin{tabular}{|c|c|c|c|c|c|c|}
\hline \multirow{2}{*}{ Attitude } & \multicolumn{2}{|c|}{ Intervention Group } & \multicolumn{2}{|c|}{ Control Group } & \multicolumn{2}{|c|}{ Total } \\
\hline & $\mathbf{n}$ & $\%$ & $\mathbf{n}$ & $\%$ & $\mathbf{n}$ & $\%$ \\
\hline Positive & 74 & 94.87 & 14 & 17.95 & 88 & 56.41 \\
\hline Negative & 4 & 5.13 & 64 & 82.05 & 68 & 43.59 \\
\hline Total & 78 & $100 \%$ & 78 & $100 \%$ & 156 & $100 \%$ \\
\hline
\end{tabular}

In Table 3, frequency distributions of respondents regarding the attitude of the use of booklet of anemia for the intervention group in the category of positive attitude and of negative attitude are 74 respondents $(94.87 \%)$ and 4 respondents $(5.13 \%)$ respectively, whereas, frequency distributions of respondents regarding the attitude of the use of booklet of anemia for the control group in the category of positive attitude and of negative attitude are 14 respondents $(17.95 \%)$ and 64 respondents $(82.05 \%)$ respectively. 
Table 4. Frequency distributions of the category of hemoglobin levels of respondents for the use of booklet of anemia

\begin{tabular}{|c|c|c|c|c|c|c|}
\hline \multirow{2}{*}{ Hb Levels } & \multicolumn{2}{|c|}{ Intervention Group } & \multicolumn{2}{|c|}{ Control Group } & \multicolumn{2}{|c|}{ Total } \\
\hline & $\mathbf{n}$ & $\%$ & n & $\%$ & $\mathbf{n}$ & $\%$ \\
\hline Normal Hb level (12-16 gr/dL) & 73 & 93.59 & 38 & 48.72 & 111 & 71.15 \\
\hline Non-normal $\mathrm{Hb}$ level $(<12$ gr/dL) & 5 & 6.41 & 40 & 51.28 & 45 & 28.85 \\
\hline Total & 78 & $100 \%$ & 78 & $100 \%$ & 156 & $100 \%$ \\
\hline
\end{tabular}

In Table 4, frequency distributions of respondents concerning the hemoglobin levels for the use of booklet of anemia in the intervention group in the category of normal $\mathrm{Hb}$ level $(12-16 \mathrm{gr} / \mathrm{dL}$ of blood) and non-normal $\mathrm{Hb}$ level $(<12 \mathrm{gr} / \mathrm{dL}$ of blood) are 73 respondents $(93.59 \%)$ and 5 respondents $(6.41 \%)$ respectively, whereas, frequency distributions of respondents regarding the hemoglobin levels for the use of booklet of anemia in the control group in the category of normal $\mathrm{Hb}$ level $(12-16 \mathrm{gr} / \mathrm{dL}$ of blood $)$ and non-normal $\mathrm{Hb}$ level $(<12 \mathrm{gr} / \mathrm{dL}$ of blood) are 38 respondents (48.72\%) and 40 respondents (51.28\%) respectively.

\subsection{Bivariate Analysis}

Table 5. Results of normality test for the use of booklet of anemia concerning knowledge of adolescent girls

\begin{tabular}{lllll}
\hline Booklet of Anemia & $\mathbf{n}$ & Statistics & Df & Sig.(2-Tailed) \\
\hline Control Group & 78 & 0.100 & 77 & 0.051 \\
Treatment Group & 78 & 0.100 & 77 & 0.053 \\
\hline
\end{tabular}

As shown in Table 5, data indicate normal distribution as shown in $p$-values for respondents in the control group and the treatment group of 0.051 and $0.053>\alpha(0.05)$. Therefore, independent samples t-test was subsequently conducted because data in the intervention group and the control group indicated normal distribution.

Table 6 . The effectiveness of booklet of anemiaon the knowledge between the intervention group and the control group

\begin{tabular}{lllll}
\hline & Booklet of Anemia & t & Df & Sig.(2-Tailed) \\
\hline Knowledge & Equal variances assumed & -7.095 & 154 & 0.000 \\
\hline
\end{tabular}

In Table 6, $p$-value $(0.000)<(0.05)$ or $\mathrm{t}_{\text {calculated }}(-7.095)>\mathrm{t}_{\text {table }}(-11.795)$. Accordingly, $\mathrm{H}_{0}$ was rejected and Ha was accepted, meaning that there were statistically significant difference of knowledge on the effectiveness of booklet on the knowledge between the intervention group and the control group.

Table 8. Results of normality test for the use of booklet of anemia concerning the attitude of adolescent girls

\begin{tabular}{lllll}
\hline Booklet of Anemia & $\mathbf{n}$ & Statistics & Df & Sig.(2- Tailed) \\
\hline Control Group & 78 & 0.100 & 77 & 0.051 \\
\hline Treatment Group & 78 & 0.92 & 77 & 0.099 \\
\hline
\end{tabular}

In Table 8, data indicate normal distribution as denoted in Sig. (2-Tailed) or $p$-value for the control group $(0.051)>$ $\alpha(0.05)$ and $p$-value or value of Sig. (2-Tailed) for the intervention group $(0.099)>\alpha(0.05)$. Because data indicate normal distribution for the intervention group and the control group, independent samples t-test was subsequently conducted for both the intervention group and the control group. 
Table 9. The effectiveness difference of booklet of anemiaon the attitude of respondents in the intervention group and the control group

\begin{tabular}{lllll}
\hline & Booklet of Anemia & t & Df & Sig. (2 - Tailed) \\
\hline Attitude & Equal variances assumed & -6.882 & 154 & 0.000 \\
\hline
\end{tabular}

As shown in Table 9, Sig. (2-Tailed) or $p$-value $(0.000)<\alpha(0.05)$ or $\mathrm{t}_{\text {calculated }}(-6.882)>\mathrm{t}_{\text {table }}(-11.603)$. Therefore, Ho was rejected and Ha was accepted, meaning that there was significant different attitude between the intervention group and the control group pertaining to the effectiveness of the use of booklet of anemia on the attitude of respondents.

Table 10. Results of normality test for the use of booklet of anemia concerning $\mathrm{Hb}$ level of anemia adolescent girls

\begin{tabular}{lllll}
\hline Booklet of Anemia & $\mathbf{n}$ & Statistics & Df & Sig. (2 - Tailed) \\
\hline Control Group & 78 & 0.95 & 77 & 0.079 \\
Treatment Group & 78 & 0.76 & 77 & 0.200 \\
\hline
\end{tabular}

In Table 10, the data showed normal distribution as indicated in the Sig. (2-Tailed) or $p$-valuefor the control group and the intervention group were 0.079 and $0.200>\alpha(0.05)$. For that reason, independent samples t-test was then conducted because data showed normal distribution.

Table 11. The effectiveness difference of booklet of anemia on the $\mathrm{Hb}$ levels between the intervention group and the control group

\begin{tabular}{lllll}
\hline & Booklet of anemia & t & Df & Sig.(2-Tailed) \\
\hline Hb levels & Equal variances assumed & -10.310 & 154 & 0.000 \\
\hline
\end{tabular}

As shown in Table 11, Sig. (2-Tailed) or $p$-value $(0.000)<\alpha(0.05)$ or $t_{\text {calculated }}(-10.310)>t_{\text {table }}(-11.683)$. Accordingly, Ho was accepted and Ha was rejected, meaning that there were statistically significant different of the effect of booklet of anemia on the $\mathrm{Hb}$ levels between the control group and the intervention group.

\section{Discussion}

\subsection{Effectiveness of Booklet of Anemia on the Knowledge of Respondents}

Knowledge of adolescent girls at the State Senior High School KutalimBaru in Deli Serdang Regency in 2018 regarding the use of booklet of anemia for the intervention group $(\mathrm{n}=78)$ in the category of good, of moderate, and of poor are 28 respondents $(35.90 \%), 45$ respondents $(2.9 \%)$ and 5 respondents $(5.9 \%)$ respectively, whereas, frequency distributions of respondents $(\mathrm{n}=78)$ regarding the knowledge of the use of booklet of anemia for the control group in the category of good, of moderate, and of poor are 4 respondents $(5.13 \%), 47$ respondents $(60.26 \%)$ and 27 respondents (34.62\%) respectively.

Results of this present study concerning the use of booklet of anemia is not consistent with those of the study of Angadi and Ranjitha (2015) among girls aged 11-15 years from five government schools in urban slums of Davangere City, Karnataka, India that knowledge of adolescent girls was not sufficiently showed significant impacts to the attitude and practice for preventing anemia among girls due to behavioral and physiological factors as well as socioeconomic limitations.

Results of this present study are consistent with the concept of Notoatmodjo (2010) that knowledge is derived from self-experience and other individuals. In this regard, there was a need for education of individuals concerning iron deficiency anemia. The findings indicated that there were poor knowledge, unfavorable attitude and poor practice about the iron deficiency anemia among the students. It was found that the main source of information for the students were family members and school teachers. The teachers and family members training will likely increase students' knowledge, influence their attitudes and motivate their practice.

It is widely acknowledged that no specific curriculum in schools particularly in developing countries that convey the topic of anemia. Other determinants are surrounding environmental factor and self-experience. Surrounding 
environment gives significant impact on the internalization of knowledge. Interactions between surrounding environment and individual give outcomes to the understanding of knowledge. It means that experience is the source of knowledge as one of the ways to gain the truth of knowledge to search for solutions from past problems. From these experiences, individuals learn on how to grasp certain knowledge for their well-being.

\subsection{Effectiveness of Booklet of Anemia on the Attitude of Respondents}

As shown in this present study, attitude of adolescent girls at the State Senior High School KutalimBaru in Deli Serdang Regency in 2018 regarding the use of booklet of anemia for the intervention group $(n=78)$ in the category of positive attitude and of negative attitude are 74 respondents (94.87\%) and 4 respondents (5.13\%) respectively, whereas, frequency distributions of respondents regarding the attitude of the use of booklet of anemia for the control group in the category of positive attitude and of negative attitude are 14 respondents (17.95\%) and 64 respondents $(82.05 \%)$ respectively.

Attitudes are aligned with behavior, indicating that behaviors can inform attitudes (Fishbein, 1967), and attitudes are influential in attention (Hoffman, 1986) in agreement with the theory of three components of attitude: cognitive, affective, and conative (Ajzen, 1993; Albert et al., 1989; Erwin, 2001; Gable \& Wolf, 1993). The cognitive component is a belief or idea associated with a particular psychological object. The affective component represents the individual's evaluation of the psychological object as well as the emotion associated with that object. The conative - or behavioral — component represents the overt action or predisposition toward action directed toward that object. Though perspectives may vary, commonalities among the viewpoints regarding attitudes are evident. Thus, attitudes can impact what an individual perceives and therefore impacts knowledge gains. Gaining good knowledge is a prerequisite to any individual aimed at boosting transformation of attitude from negative attitude to be positive attitude. As described in the concept of Notoatmodjo (2005), a complete whole of attitude, knowledge, insight, belief and psychological condition have pivotal roles to transform positive attitude to perform effort in preventing anemia.

\subsection{Effectiveness of Booklet of Anemia on the Hb Levels of Respondents}

Results of the study at the State Senior High School 1 KutalimBaru in Deli Serdang revealed there were significant differences of $\mathrm{Hb}$ levels of adolescent girls between the intervention group (treatment) and the control group that the booklet gave significant impact to the knowledge, behaviors and practice in preventing anemia.

The most important determinants of anemia among respondents observed in this present study were menstrualtion per month and misunderstanding of practice of dietary habits and consumption of fast food. This coincides with the study of Arini et al. (2017) in Bangli regency, Bali, Indonesia, that iron supplementation at a dose twice a week for 3 consecutive months could decreased the prevalence of anemia in teenage girls as much as $24.9 \%$ with the increase of $\mathrm{Hb}$ levels ranged from 142 to $220 \mathrm{~g} / \mathrm{dL}$ Moreover, it is also consistent with the study of Hamal et.al (2018) in Nepal that assessed the prevalence of anemia and its associated factors among school adolescent girls in Baglung municipality in which adolescent period is more vulnerable among girls due to rapid growth, dietary insufficiency, menarche, excessive menstrual bleeding and other acute infection like worm infestation which may demand high iron supplementation to maintain the iron level in the body.

Results of this present study are compatible with those of the study of Jalambo et al. (2017) in Palestine that nutrition education intervention has an impact on improving knowledge, attitude and practices of iron-deficient female adolescents compared with the control group and suggested to adopt and integrate nutrition programme with comprehensive intervention programmes to target iron deficiency anemia among adolescents at various levels. Therefore, the school health program is a potential strategy to increase the iron status as well as improving the general health and nutritional status of student adolescent girls (Kurniawan et al., 2006).

This fact coincides with the report of WHO (2011) that the need of iron supplementation to restore loss iron for adolescent girls during menstruation was $12.5-15 \mathrm{mg}$ per month or $0.4-0.5 \mathrm{mg}$ per day. This is compatible with results of the National Household Health Survey in 2012 that the majority of individuals who had anemia were $57.1 \%$ in the category of 10-18 years of age (Ministry of Health of the Republic of Indonesia, 2013). This is due to rapid pubertal growth with sharp increase in lean body mass, blood volume, and red cell mass, which increases iron requirements for myoglobin in muscles and $\mathrm{Hb}$ in the blood. Iron requirement increases two- to threefolds from a preadolescent level of $\sim 0.7-0.9 \mathrm{mg}$ iron/day to as much as $1.40-3.27 \mathrm{mg}$ iron/day in adolescent girls (WHO, 2011).

Health management for preventinganemia by giving iron supplementation to fertile women still provide priority to pregnant women by giving 90 tablets that contain iron element during pregnancy in pregnant women. It is wise that this approach can also be practiced to adolescentgirls considering to the fact that adolescentgirls will be 
prospective mothers to anticipate early anemia cases by consume tablets that contain iron element once a week during menstruation (Ministry of Health of the Republic of Indonesia, 2014).

\section{Conclusions}

Based on results and discussion of the study concerning the effectiveness of booklet of anemia on the behavior of adolescentgirls pertaining to anemia at the State Senior High School 1 Kutalim Baru in Deli Serdang, in 2018, the authors of this study drew the following conclusions:

1) Booklet gave significant impact to the improvement of knowledge of anemia.

2) Booklet gave significant impact to the improvement of attitude of anemia.

3) Booklet gave significant impact on the improvement of hemoglobin levels.

\section{Suggestions}

\subsection{To Medan Health Polytehnic, Ministry of Health}

It is hoped for health institutions to increase and to distribute up-date health guidance pertaining to behavioral changes regarding anemia among adolescent girls.

\subsection{To State Senior High School 1 Kutalim Baru of Deli Serdang Regency}

It is expected to motivate and to practice continuously counseling pertaining to anemia among adolescent girls at the State Senior High School 1 KutalimBaru ofDeli Serdang Regency by practicing healthy behaviors regarding consumption of balanced nutritious foods and tablets that contain iron element once a week.

\subsection{Furter Studies}

To perform further studies pertaining to anemia by adding more other variables related with the practice of booklet of anemia for adolescent girls in enhancing their healthy behaviors, such as menstruation, eating behaviors, resting pattern and other healthy behaviors associated with anemia.

\section{Acknowledgments}

The authors are grateful also for the revieweers to valuable comments and their constructive comments and suggestions of great benefit to this paper.

\section{Competing Interests Statement}

The authors declare that there are no competing or potential conflicts of interest.

\section{References}

Ajzen, I. (1993). Attitude theory and the attitude-behavior relation. In D. Krebs \& P. Schmidt (Eds.), New directions in attitude measurement (pp. 41-57). New York: Walter de Gruyter.

Albert, D., Aschenbrenner, K. M., \& Schmalhofer, F. (1989). Cognitive choice processes and the attitude-behavior relation. In A. Upmeyer (Ed.), Attitudes and behavioral dimensions (pp. 61-99). New York: Springer-Verlag. https://doi.org/10.1007/978-1-4612-3504-0_3

Anand, I. S. (2008). Anemia and chronic heart failure implications and treatment options. J Am CollCardiol., 52(7), 501-511. https://doi.org/10.1016/j.jacc.2008.04.044

Angadi, N., \& Ranjitha, A. (2016). Knowledge, attitude and practice about anemia among adolescent girls in urban slums of Davangere City, Kamataka. International Journal of Medical Science and Public Health, 5(3). https://doi.org/10.5455/ijmsph.2016.2007201570

Arini, N., Bakte, M., \&Citrawati, D. M. (2017). The impact of iron supplementation toward hemoglobin levels on teenage girls in Bangli regency, Bali, Indonesia. International Journal of Research in Medical Sciences, 5(8), 3545-3457. https://doi.org/10.18203/2320-6012.ijrms20173539

Baral, K., \& Onta, S. (2009). Prevalence of anemia amongst adolescents in Nepal a community based study in rural and urban areas of Morang District. Nepal Med Coll J., 11(3), 179-182.

Beard, J. L., \& Connor, J. R. (2003).Iron status and neural functioning. Annu Rev Nutr., 23, 41-58. https://doi.org/10.1146/annurev.nutr.23.020102.075739

Brabin, B. J., Hakimi, M., \& Pelletier, D. (2001). An analysis of anemia and pregnancy-related maternal mortality. $J$ Nutr., 131(2S-2), 604S-614S, discussion 614S-615S.

Ciesla, B. (2011). Hematology in Practice (2nd ed.). Philadelphia, PA: FA Davis Company; 2011. [Google 
Scholar]

Demographic and Health Survey (DHS). (2012). Key Indicators Survey 2006. Retrieved from http://www. measuredhs.com/What-We-Do/Survey-Types/KIS.cfm

Demographic and Health Survey (DHS). (2012). Model Questionnaire -Phase 5- (2003-2008). Retrieved from http://www.measuredhs.com/ publications/publication-DHSQ5-DHS-Questionnaires-and-Manuals.cfm

Dunne, J. R., Malone, D., Tracy, J. K., Gannon, C., \& Napolitano, L. M. (2002). Perioperative anemia: an independent risk factor for infection, mortality, and resource utilization in surgery. J Surg Res., 102(2), 237-244. https://doi.org/10.1006/jsre.2001.6330

Erwin, P. (2001). Attitudes and persuasion. Philadelphia: Taylor \& Francis Inc.

Fishbein, M. (1967). Attitude and the prediction of behavior. In M. Fishbein (Ed.), Readings in attitude theory and measurement (pp. 477-492). New York: John Wiley \& Sons.

Gable, R. K., \& Wolf, M. B. (1993). Instrument development in the affective domain: Measuring attitudes and values in corporate and school settings (2nd ed.). Boston, MA: Kluwer Academic Publishers. https://doi.org/10.1007/978-94-011-1400-4

Glazer, Y., \& Bilenko, N. (2010). [Effect of iron deficiency and iron deficiency anemia in the first two years of life on cognitive and mental development during childhood] [in Hebrew]. Harefuah, 149(5), 309-314, 335. https://doi.org/10.1093/jn/131.2.604S

Haas, J. D., \& Fairchild, M. W. (1989). Summary and conclusions of the International Conference on Iron Deficiency and Behavioral Development, October 10-12, 1988. Am J ClinNutr., 50(3), 703-705. https://doi.org/10.1093/ajen/50.3.703

Hamnal, H., Dhungana, G. P., Shrestha, P., \& Niraj, K. C. (2018). Prevalence of anemia and its associated factors among school adolescent girls in Baglung municipality, Nepal. Global Journal of Medicine and Public Health, 5.

Hamulka, J., Wadolowska, L., Hoffmann, M., Kowalkowska, J., \& Gutkowska, K. (2018). Effect of an education program on nutrition knowledge, attitudes toward nutrition, diet quality, lifestyle, and body composition in Polish teenagers. The ABC of healthy eating project: design, protocol, and methodology. Nutrients, 10(10), 1439. https://doi.org/10.3390/nu10101439

Hoffman, M. L. (1986). Affect, cognition, and motivation. In R. M. Sorrentino and E. T. Higgins (Eds.), Handbook of motivation and cognition (pp. 244-280). New York: Guilford Press.

Jalambo, M. O, Sharif, R., Naser, I. A., Norimah, A., \& Karim, N. A. (2018).Improvement in knowledge, attitude and practice of iron deficiency anaemia among iron-deficient female adolescents after nutritional educational intervention. Global Journal of Health Science, 9(7). https://doi.org/10.5539/gjhs.v9n7p15

Kurniawan, Y. A. I., Muslimatun, S., Achadi, E. L., \& Sastroamidjojo, S. (2006). Anaemia and iron deficiency anaemia among young adolescent girls from peri urban coastal area of Indonesia. Asia Pac J ClinNutr, 15(3), 350-356.

Lim, Z. X., Wong, J.L., Lim, P. Y., \& Soon, L. K. (2018). Knowledge of nutrition during pregnancy and associated actors among antenanatal mothers. International Journal of Public Health and Clinical Sciences, 5(1).

McCann, J. C., \& Ames, B. N. (2007). An overview of evidence for a causal relation between iron deficiency during development and deficits in cognitive or behavioral function. Am J Clin Nutr., 85(4), 931-945. https://doi.org/10.1093/ajen/85.4.931

McLean, E., Cogswell, M., Egli, I., Wojdyla, D., \& de Benoist, B. (2009). Worldwide prevalence of anaemia, WHO vitamin and mineral nutrition information system, 1993-2005. Public Health Nutr, 12(4), 444-454. https://doi.org/10.1017/S1368980008002401

Ministry of Health of the Republic of Indonesia. (2013). National Household Health Survey.

Ministry of Health of the Republic of Indonesia. (2014). National Health Survey.

Mitra, M., Wan Abdul Manan, W. M., Affizal, A., MohdShukri, O., \& Maryam, M. (2012). Does nutritional knowledge have a relationship with healthy dietary attitude and practices during pregnancy? International Proceedings of Chemical, Biological \& Environmental, 39, 159-163.

Notoatmojo, S. (2012). MetodologiPenelitianKesehatan (Research Methodology for Health Sciences). 
RinekaCipta Inc. Jakarta. [In Indonesia language]

Rasmussen, K. M. (2001). Is there a causal relationship between iron deficiency or iron-deficiency anemia and weight at birth, length of gestation and perinatal mortality? $J$ Nutr., 131(2S-2), 590S-601S, discussion 601S-603S. https://doi.org/10.1093/jn/131.2.590S

Regional Health Department of North Sumatera, 2017. North Sumatera Health Survey.

Sachdev, H., Gera, T., \& Nestel, P. (2010). Effect of iron supplementation on mental and motor development in children: systematic review of randomized controlled trials. Public Health Nutr., 8(2), 117-132. https://doi.org/10.1079/PHN2004677

Shojaeizadeh, D. (2001). A Study on Knowledge, Attitude and Practice of Secondary School Girls in Qazvin on Iron Deficiency Anemia. Iranian J. Publ. Health, 30(1-2), 53-56.

Sinaga, L. V. (2013). The effect of eating behaviors on anemia incidences among adolescents (Magistrate Education Thesis. Postgraduate Program of Public Health Sciences. North Sumatera University).

Spear, B. A. (2002). Adolescent growth and development. Journal of the American Dietetic Association, 102, 23-29. https://doi.org/10.1016/S0002-8223(02)90418-9

Spronk, I., Kullen, C., Burdon, C., \& O'Connor, H. (2014). Relationship between nutrition knowledge and dietary intake. Br. J. Nutr., 111, 1713-1726. https://doi.org/10.1017/S0007114514000087

Tesfaye, M., Yemane, T., Adisu, W., Asres, Y., \& Gedefaw, L. (2015). Anemia and iron deficiency among school adolescents: burden, severity, and determinant factors in southwest Ethiopia. Adolesc Health Med Ther, 6, PMC4687608.

World Health Organization [WHO]. (2001). Iron deficiency anemia. Assessment, prevention and control.UNICEF/UNU/WHO. Retrieved from: http//www.int/nutrition/publications/micronutrients/anemiairon-deficiency/WHO-NHD-./en/

World Health Organization [WHO]. (2012). Micronutrient deficiencies: Iron deficiency anemia. Retrieved from: http://www.who.int/nutrition/ topics/ida/en/index.html

\section{Copyrights}

Copyright for this article is retained by the author(s), with first publication rights granted to the journal.

This is an open-access article distributed under the terms and conditions of the Creative Commons Attribution license (http://creativecommons.org/licenses/by/4.0/). 